\title{
IMPLEMENTATION OF MIND MAPPING TECHNIQUE TO IMPROVE STUDENTS' READING COMPREHENSION IN DESCRIPTIVE TEXT
}

\author{
Rini Hendrita ${ }^{1}$, Sumitra Putri Dewi ${ }^{2}$ \\ ${ }^{1}$ Pendidikan Bahasa Inggris, FKIP UM-Sumatera Barat \\ email: rinihendrita06@gmail.com
}

\begin{abstract}
This research is about the implementation of mind mapping technique to improve students reading comprehension in descriptive text at grade VIII SMP N 1 Sintuk Toboh Gadang. This research was classified as pre-experimental research. The subjects of this research were 32 students of class VIII-1 of SMP N 1 Sintuk Toboh Gadang. The data was quantitative data taken from pre-test and post-test. The result of this research showed that the implementation of mind mapping technique on teaching reading was effective. It can be seen in the pre-test and post-test score. The pre-test mean is 50,93 and the post-test mean is 83,44. If it reviewed from $t_{\text {count }}$ and $t_{\text {table }}$ with $\alpha$ is 0,05 . It means $t_{\text {count is }}$ higher than $t_{\text {table }}$ (21,8237 > 2,039). Based on the data, it can be concluded that mind mapping technique is appropriate to be applied in teaching reading comprehension, particularly at grade VIII SMP N 1 Sintuk Toboh Gadang.
\end{abstract}

Keywords: reading comprehension, mind mapping technique, descriptive text.

\section{INTRODUCTION}

Reading is very essential in learning English to get information from written English. In the reading activity, the reader should interpret the meaning of the written text. Snow (2002) states that reading comprehension is the ability to obtain knowledge and information from written text. the Reader needs to be able to comprehend what they are reading that involves the process of acquiring grammatical structures, vocabulary, and meaning. It means that students in demand must understand the content of the text they read and find important points or information in the text.

In some situations, reading in the first language is very different from a foreign language. Fact, reading a foreign language is more difficult than reading the first language. Nuttal, Cristine (1996) said that it is found in Indonesian students encounter reading difficulties as foreign language learner such as, read slowly word by word, incompetence to apply reading strategy, easy frustrated and dissatisfied particularly when they meet some difficulty words, read the text aloud in which it may inhibit comprehension, and they confuse to read authentic text in foreign language. 
Based on an observation that has been done at school, the researcher found some problems in teaching a reading text. There are some factors why the student cannot comprehend a text. Firstly, from the student, some of the students had difficulties to comprehend the text because they had fewer vocabularies and looked bored and lazy to read the text. Secondly, from the teacher the researcher assumes that a technique applied at the time was a common technique used by the teacher. It made the reading lesson not interesting and students got low score on their reading test. It can conclude, these both factors influenced the student motivation and their achievement in reading.

To overcome the problems above, the researcher assumes that there should be some suitable techniques in teaching reading to motivate the students to read all the texts so they can get the information fully. There are many ways and techniques to increase students' reading ability. One of them is by using a mind mapping technique. The mind mapping is a technique to use the whole brain by using visual and other graphics to create a meaningful impression (DePotter and Hernacki: 2004). Using the whole brain can balance two sides of the human brain: the left and right brain. It means that humans can maximize their brains to create meaningful things because of their brains' power.

Fact, teaching reading by using mind mapping is not a new issue in the English language. The mind mapping technique has been applied in many studies. Buzan (2003) argues that children can learn an interesting way using a certain technique which is called Mind Mapping. In addition, mind mapping is a cognitive strategy that helps to improve the students' ability in reading such as note-taking and summarizing the crucial information for better understanding and memorization (Beare, 2009). The use of mind mapping makes it possible to create meaningful reading experiences for students in the classroom. Mind mapping can be easily implemented to modify different teaching styles and providing an opportunity to the teachers, making their learning extremely simple for all.

In this research, the researcher focuses on reading comprehension of descriptive text. According to Fulwiller (2002), descriptive text is a text that describes a person, place, or thing. It is to create a verbal image so that readers can see what you see, hear what you hear, and taste, smell, feel what you taste, smell, and feel. In accordance with Fulwiller, wadirman, et.al (2008) states that a descriptive text as a text that describes the features of someone, something, or a certain place. It can be inferred that a descriptive text is a text which describes characteristic of particular place, person, or thing.

\section{RESEARCH METHOD}

This research used pre-experiment research. Sukardi (2007) stated that pre-experimental research as the simple research that uses singular variable is the research that used individual or group as the subject of study. Then this research is used to know whether using MM (Mind Mapping) Technique is effective or not. 
The pre-experiment class given a technique that is Mind Mapping

Table 3.1 Pre-Experimental Research

\begin{tabular}{|c|c|c|c|}
\hline Class & Pre-test & Treatment & Post-test \\
\hline Experimental & $\mathrm{X} 1$ & $\mathrm{~T}$ & $\mathrm{X} 2$ \\
\hline
\end{tabular}

Source: Suryabrata (2004)

Notes :

$\mathrm{T}=$ Treatment with the application of Mind Mapping Technique (MMT)

$\mathrm{X} 1=$ Pre-test

$\mathrm{X} 2=$ Post-test

In this pre-experiment research, the researcher used quantitative research. The population of research was Eight Grade students of SMP N 1 Sintuk Toboh Gadang in Academic years 2019/2020. Sugiyono (2008) defined population is the generalization region consisting of an object or subject that has certain qualities and characteristics defined by the researcher to learn and then draw conclusions. In this research, the researcher used purposive sampling. Sugionyo (2010) defined purposive sampling as the technique of determining the sample based on certain considerations. The sample of this research was class VIII-1 grade students of SMP N 1 Sintuk Toboh Gadang which consisted of 32 students. The instrument used in this research was reading test for collecting data. The reading test was given in pre-test and post-test in multiple-choice form. The try-out was administered before giving the pre-test. It was expected to find out whether the test items used in the research were good or not. It refers to validity, reliability, level of difficulty, and discrimination. This test was conducted in 45 minutes.

\section{RESULT AND DISCUSSION}

From the result of the research, it can be seen that pre-test minimum score is 20 , the pre-test maximum score is 70 , only twelve students who got the score above KKM (kkm is 60) and the mean score of class in pre-test is 50,9375. Meanwhile, the post-test minimum score is 70, the post-test maximal score is 100 . From the difference between pre-test and post-test scores, it can be seen that using of Mind Mapping Technique on teaching reading comprehension is effective.

In pre-test there are five indicators in reading comprehension such as Purpose, fact, context, vocabulary, and inference.

First, Students' percentage indicators purpose contained in item number 3 and 4. For item number 3, from 32 students were 6 students $(18,75 \%)$ fill the correct answer, and the students fill Incorrect answer were 26 students $(81,25 \%)$. For the item number 4, from 32 students were 27 (84,38\%) fill the correct answer and $5(15,63 \%)$ Students fill Incorrect answer. Based on descriptions above, it can 
be seen the percentage of students' score in purpose was medium. The total percentage of the indicator was $51,56 \%$ the students, it means the students not yet comprehend the purpose of reading the descriptive text.

Second, students' percentage indicators fact contained in item number 5 . For item number 5, from 32 students were 26 students $(81,25 \%)$ fill the correct answer, and the students fill Incorrect answer were 6 students (18,75\%). Based on the descriptions above, it can be seen the total percentage of students' score was $81,25 \%$.

Third, students' percentage indicators context that contained in item numbers 7, 8 and 9. For item number 7, from 32 students were 5 students $(15,63 \%)$ fill the correct answer, and the students fill Incorrect answer were 27 students $(81,25 \%)$. For item number 8 , from 32 students were $22(68,75 \%)$ fill the correct answer and $10(31,25 \%)$ students fill Incorrect answers. For item number 9 , from 32 students were $28(87,50 \%)$ fill the correct answer and $4(12,5 \%)$ students fill Incorrect answers. Based on the descriptions above, it can be seen the percentage of students' scores in context was 57,29 \%, The students still not comprehend yet about the context in reading the descriptive text.

Fourth, students' percentage indicators vocabulary contained in item number 2 and 6. For item number 2, from 32 students were 6 students $(18,75 \%)$ fill the correct answer, and the students fill Incorrect answer were 26 students $(81,25 \%)$. For item number 6 , from 32 students were $22(68,75 \%)$ fill the correct answer and $10(31,25 \%)$ Students fill Incorrect answer. Based on the descriptions above, it can be seen the percentage of students' scores in vocabulary was $43,75 \%$. The students not yet comprehend the Vocabulary in reading the descriptive text.

Fifth, students' percentage indicators Inference contained in item numbers 1 and 10 . For item number 1 , from 32 students were 12 students $(37,50 \%)$ fill the correct answer, and the students fill Incorrect answer was 20 students (62,5\%). For item number 10, from 32 students were $11(34,38 \%)$ fill the correct answer and $21(65,63 \%)$ Students fill Incorrect answer. Based on the descriptions above, it can be seen the percentage of students' scores in Inference was low. The total percentage of the indicator was $35,94 \%$ of the students. The students not yet comprehend the inference in reading the descriptive text.

While in the post-test, students' percentage indicators purpose contained in item number 3 and 4. For item number 3, from 32 students were 32 students $(100 \%)$ fill the correct answer. For item number 4, from 32 students were 32 $(100 \%)$ fill the correct answer too. Based on the descriptions above, it can be seen the percentage of students' scores in this indicator. There was the effectiveness in the implementation of using mind mapping in teaching reading comprehension on descriptive text. The total percentage of this indicator is increasing from 51,56\% to $100 \%$.

Then, students' percentage indicators fact contained in item number 5. For item number 5, from 32 students were 30 students $(93,75 \%)$ fill the correct 
answer, and the students fill Incorrect answer were 2 students $(6,25 \%)$. Based on the descriptions above, it can be seen the percentage of students' scores in this indicator. There was the effectiveness in the implementation of using mind mapping in teaching reading comprehension on descriptive text. The total percentage of this indicator is increased from $81,25 \%$ to $93,75 \%$.

In students' percentage indicators context that contained in item numbers 7, 8 and 9. For item number 7, from 32 students were 24 students $(75 \%)$ fill the correct answer, and the students fill Incorrect answer were 8 students (25\%). For item number 8, from 32 students were $29(90,63 \%)$ fill the correct answer and 3 $(9,38 \%)$ students fill Incorrect answer. Item number 9 was 32 students (100\%) fill the correct answer. Based on the descriptions above, it can be seen the percentage of students' scores in this indicator. There was the effectivenes in the implementation of using mind mapping in teaching reading comprehension on descriptive text. The total percentage of this indicator is increased from 57,29\% to $88,54 \%$.

Then, students' percentage indicators vocabulary contained in item number 2 and 6. For item number 2, from 32 students were 13 students (40,63\%) fill the correct answer, and the students fill Incorrect answer were 19 students $(59,38 \%)$. For item number 6 , from 32 students were 32 (100\%) fill the correct answer. Based on the descriptions above, it can be seen the percentage of students' scores in this indicator. There was the effectivenes in the implementation of using mind mapping in teaching reading comprehension on descriptive text. The total percentage of this indicator is increased from $43,75 \%$ to $70,31 \%$.

The last students' percentage indicators inference contained in item numbers 1 and 10. For item number 1, from 32 students were 21 students $(65,63 \%)$ fill the correct answer, and the students fill Incorrect answer were 11 students $(34,38 \%)$. For item number 10, from 32 students were $21(65,63 \%)$ fill the correct answer and $11(34,38 \%)$ Students fill Incorrect answer. Based on the descriptions above, it can be seen the percentage of students' scores in this indicator. There was the effectiveness in the implementation of using mind mapping in teaching reading comprehension on descriptive text. The total percentage of this indicator is increased from $35,94 \%$ to $65,63 \%$.

Based on the result of this research There was the effectiveness of implementation using the mind mapping technique to improve reading comprehension in descriptive text. It can be seen in the pre-test and post-test. It showed an increase in the percentage of students' scores. The difference between pre-test and post-test mean is 83,44 . The difference between pre-test and post-test in indicator (Purpose) is 48,44\%. The difference between pre-test and post-test in indicator (Fact) is $12,5 \%$. The difference between pre-test and post-test in indicator (Context) is $31,25 \%$. The difference between pre-test and post-test in indicator (Vocabulary) is 26,69 \%. The difference between pre-test and post-test in indicator (Inference) is $29,69 \%$. 
In hypothesis test used t-Test: Paired Two Sample for Means. The result is : In The $t_{\text {count }}$ price is $-21,8237$. It means the students reading comprehension in descriptive text understanding is enhanced after using the mind mapping technique on teaching. If it reviewed from $t_{\text {count }}$ and table with $\alpha$ is 0,05 . It means $t_{\text {count }}$ higher than $t_{\text {table }}(-21,8237>2,039)$. Based on the description above $\mathrm{H} 0 \neq 0$ and $\mathrm{H} 1=0$. It means there is an effect of mind mapping technique toward reading comprehension in descriptive text. So, using the mind mapping technique on teaching reading at VIII grade students of SMP N 1 Sintuk Toboh Gadang was effective.

\section{CONCLUSIONS}

After conducting the treatments and analyzing the data gained, the researcher takes some conclusions as follows: Mind mapping can be applied as one of the techniques to improve student's reading comprehension in the descriptive text. It could be seen from the gain of the students' reading mean score in the pre-test and the post-test (50,9375 to 83,4375). Mind mapping can help students to improve their comprehension in reading descriptive text in terms of purpose, fact, context, vocabulary, and inference by seeing the analysis of the students' works in the pre-test and post-test in each aspect. There was a significant increase of students' reading comprehension after being taught through mind mapping technique at SMP N 1 Sintuk Toboh Gadang. It also can be seen from the result of the hypothesis testing which showed that the Sig. $<\alpha(p<0.05$, $\mathrm{p}=0.000$ ). So. it showed that the using mind mapping technique was effective to teach reading, especially teaching reading comprehension in descriptive text.

\section{ACKNOWLEDGEMENT}

The researcher would like to express their deepest appreciation and thankfulness to the principal SMP N 1 Sintuk Toboh Gadang who had permitted and facilitated the researchers in conducting their research, also all students at grade XIII, and English teachers who have cooperated so well while this research conducting.

\section{REFERENCES}

Brown, H. D. 2004. Language Assessment:Teaching by Principles: An Interactive Approach to Language Pedagogy Second Edition. New York: Pearson Education Company.

Buzan, T. (2003). Mind Maps for Kids. English: Thorson.

Davies, P., \& Pears, Eric. 2000. Success in English Teaching. Oxford: Oxford University Press.

DePotter, \& Hernacki. 2004. Quantum Learning: Membiasakan Belajar Nyaman dan Menyenangkan. Bandung: Kaifa.

Fulwiler, T. 2002. College Personal Approach to Academic Writing. Poutmouth NH: Heineman.

Nuttal, C. (1996). Teaching Reading Skills In A Foreign Language; New Edition.

Snow, C. 2002. Reading for Understanding .United Stated: Rand Education. 
Wadirman, MD., Sukirman., \& Masduki, B. 2008. English in Focus for Grade VII Junior High School. Jakarta: Pusat Perbukuan Departemen Pendidikan Nasional.

Wood, D. 1988. How Children Think and Learn. Oxford, UK: Brasil BlackLtd. Sugiyono. 2008. Metode Penelitian Kuantitatif, Kualitatif dan R\&D. Bandung: Alfabeta.

Sugiyono. 2010. Metode Penelitian Kuantitatif, Kualitatif dan R\&D. Bandung:Alfabeta.

Sukardi. 2007. Metodology Penelitian Pendidikan. Yogyakarta: Bumi Aksara. 